\title{
A public choice perspective of IMF and World Bank lending and conditionality*
}

\author{
AXEL DREHER \\ University of Exeter, School of Business and Economics, Streatham Court, Rennes Drive, \\ Exeter EX4 4PU, United Kingdom; e-mail: mail@axel-dreher.de
}

Accepted 14 April 2003

\begin{abstract}
The paper explains IMF and World Bank lending and conditionality stressing changes in relative bargaining power of different stakeholders over time. It applies public choice theory to explain the interests of the institutions' member states, its borrowers and staffs as well as private actors attaching their money to the IFIs' programs. Using panel data for 43 countries between 1987-99 it is shown that the number of Fund conditions seems to be influenced by contemporaneous World Bank activity and "bad" policies.
\end{abstract}

\section{Introduction}

As IMF and World Bank were founded in Bretton Woods in 1944, there was no consideration of intrusive conditionality now common under the international financial institutions' (IFIs) programs. The IMF was created to provide short term balance of payments credits and stabilize the post war financial system. The Bank was founded to promote long term growth in its member countries. However, over time, with the evolution of the IFIs, conditionality gradually increased and became inseparably associated with their loans. Whereas an average IMF program between 1952-73 included four binding conditions, this number rose to seven between 1974-82 and twelve between 1983-95 (Gould, 2001: 6). The average number of performance criteria from 1995-99 was twelve (Goldstein, 2000: Table 4). In programs publicly available, between 1999-2001 the average number of performance criteria was about nine whereas total conditions averaged 21 (Dreher, 2002). Initially, the World Bank used much fewer conditions. Only with the inception of adjustment lending, conditions enforced by the Bank increased in number as well. Today, they are even more numerous than those of the Fund. World Bank adjustment programs between 1980-82 included, on average, 34 condi-

* The author is grateful for many helpful suggestions by Roland Vaubel, the participants of the HWWA workshop on Public Choice and Development on 9 November 2001 and the Annual Meeting of the European Public Choice Society 4-7 April 2002, especially Jakob de Haan. 
tions. This number rose to 35 in 1983-86 and 56 in 1987-90 (Dreher, 2002). These conditions complemented those of the IMF since conclusion of an IMF arrangement usually is a precondition for the Banks' adjustment lending.

Today, both Fund and Bank aim at increased growth and reduced poverty in their member countries. Their conditionality converged. Whereas the Fund initially focused on macroeconomic aspects of adjustment, today both institutions use many structural conditions. However, the number included in Bank arrangements - the majority of which are not quantifiable - is still higher (Dreher, 2002). Until the eighties the IMF only lent for balance of payments reasons. The Bank did finance programs only exceptionally but provided money for individual projects. Now, both Fund and Bank lend to support structural adjustment.

The evolution of IMF and World Bank conditionality has been described in detail in several recent papers (World Bank, 2001; IMF, 2001, 2001a, 2001b). There are papers justifying the use of conditionality - as well as those criticizing it. ${ }^{1}$ The institutions' lending practices have also been criticized (Dreher and Vaubel, 2004; IFIAC, 1999; Vaubel, 1991). This paper does not deal with such criticism. It tries to explain why lending and conditionality have evolved the way they did. In doing this, the analysis focuses on the interests of the institutions' most influential stakeholders. It is sometimes claimed that the IFIs' policies are driven by their major members, especially the U.S. government (Goldstein, 2000: 67; Frey, 1997: 121; Vaubel, 1991: 210). Others stress the influence of private actors who attach their money to the IMF's programs (Gould, 2001). Conditionality might also be influenced by borrowing countries' politicians. Those politicians can employ conditionality as a commitment device (Dhonte, 1997). In order to enhance policy credibility governments tie their hands by including their preferred policy measures in programs with the IFIs. A similar proposal points out that rejection of government's preferred policies by opponents becomes more costly when those policies are tied to conditionality (Vreeland, 2001; Vaubel, 1991). Moreover, the interests of the IFIs' staffs seem to be relevant. As is well known, international bureaucrats derive utility from income, prestige and power (Vaubel, 1991: 211). Since staff members' prestige rises with the amount of money lent and the stringency of conditionality attached to the loan, the number of conditions attached to the IFIs' programs should rise the more a country depends on their money (Mosley, Harrigan, and Toye, 1991: 125) ${ }^{2}$ and the less the Executive Directors are able or willing to control the staff.

In light of these considerations, differences in lending and conditionality over time as well as between IMF and World Bank are explained by changes in relative power and interests of different stakeholders over time. 
The paper proceeds with an analysis of Fund and Bank lending. The third section focuses on conditionality. It includes a cross-section time-series analysis of the number of IMF conditions. The final section sums up.

\section{Fund and Bank lending}

2.1. Why does the World Bank disburse its loans even if non-compliance is obvious?

Several studies showed that the Bank - contrary to the Fund - almost never cancels programs, even if non-compliance is evident (Dollar and Svensson 1998: 4; Ranis 1996: 6, Nash 1993: 24, Mosley, Harrigan, and Toye, 1991: 166). In these cases, tranches are sometimes being withheld for some time but are eventually paid out completely.

A first explanation is given by the different financial backgrounds of IMF and World Bank. Of course, both Bank and Fund do not want to retain their money. Since the Bank finances its lending with money from the capital markets, it is, however, under much more pressure to lend what is available. More than in the Fund, staff members are thus judged according to their ability to lend the money prepared for their region. It is therefore not in the interest of the staff to negotiate clear criteria which automatically interrupt programs. Compared to Fund staff, Bank employees probably prefer lending the agreed money, relative to enforcing the agreed-upon conditions (Polak, 1994: 15).

According to Kaltefleiter (1995: 155), the Bank's most important peer group are private bankers. This could enhance the World Bank's preference for full disbursement. If part of the money would be retained, this would suggest their staff could not adequately judge the projects at the outset. The staff members could thus loose prestige. For the Fund, on the other hand, the most relevant peer group are international economists. The reputation of the IMF's staff therefore increases with the quality of the program and enforcement of the conditions. As Bird (2002: 11) points out, even professional advancement within the IMF may depend to some degree on programs that appear 'tough'.

Finally, the World Bank is able to evaluate compliance completely only long after the disbursement of its money. Most of the staff members who negotiated the program are at this stage no longer in the respective region. ${ }^{3}$ Non-compliance is therefore a problem for their successors and not for themselves. Their reputation could even improve if their successors have greater problems in dealing with creditors than they had. 


\subsection{Why do Fund and Bank lend for structural adjustment?}

The World Bank's decision to engage in adjustment lending was probably influenced by the oil price shock. Officially, the Bank wanted to support developing countries which were affected by the recession in most industrial countries and worldwide inflation. However, the deterioration in non-oil developing country's external environment at the end of the seventies might have induced an unwillingness to service their debt if the expected net flow would have been negative (Polak, 1994: 10) what probably strengthened the Bank's decision. Moreover, adjustment lending provided the Bank's staff with more leverage over members' policies which increased its power and prestige.

The excess supply of IMF loans after the increase in oil prices in 1973 has probably contributed to the Funds' decision to create its Extended Facility in 1974 which gave it new possibilities to lend for structural adjustment (Polack, 1994: 8). After the break-down of the Bretton Woods system of fixed exchange rates, the Fund needed new tasks to justify its existence. Its staff therefore employed the surge in oil prices and resulting structural balance of payments imbalances to secure an increase in power, prestige, and resources (Vaubel, 1991: 213).

The IMF facilities for structural adjustment, founded in 1986 and 1987, also served the interests of the staff. After the debt crisis they were in urgent need for new tasks. In order to maintain a high level of lending, the IMF had to stimulate demand. According to Vaubel (1991: Table 4) lending under the new facilities was not additional to loans under the old ones, but rather served as substitute. Without reducing the interest for its loans, however, many former clients would not have been able to afford further credits. As Kahler (1986: 270) points out, the new facilities have been tailored to the needs of Sub-Saharan countries. Those countries had difficulties staying current on their debt service. As the World Bank engaged in structural adjustment lending partly to prevent default, the IMF disbursed new funds to permit its clients to pay their interest (Vaubel, 1991: 219).

\subsection{Why does the World Bank lend mainly to countries with access to private capital?}

Although the World Bank officially does not lend for purposes that could be financed from other sources at suitable conditions (Deutsche Bundesbank, 1997: 85), chiefly middle income countries receive its loans (IFIAC, 1999). These countries could attract private capital as well.

If the Bank has to engage in program lending anyhow, why does she grant their loans not to those countries most in need of them on humanitarian grounds? Again, public choice theory gives an answer. Since the World 
Bank finances its loans with private capital, like every other bank she needs to get the money back. Therefore she prefers those creditors whose income from exports is sufficient to service their foreign debt (Deutsche Bundesbank, 1997: 84).

Economically more developed countries often have a higher weight politically as well. They dispose over more voting rights in the Bank's Executive Board. In times of crisis, they can get loans more easily, because they are more important for the world economy. Moreover, richer countries often have closer relations to industrialized countries. The governments of those countries might lobby the Bank to disburse higher loans.

\section{Fund and Bank conditionality}

\subsection{Why has IMF and World Bank conditionality changed and why do the institutions' conditions differ?}

One of the most important changes in conditionality is the increase in the number of conditions over time. During the negotiations in Bretton Woods, the U.S. position was fundamentally different from those of most other countries. As a consequence, the IMF's Articles did not include guidelines on conditionality and the Executive Board had to decide on that topic. Executive Directors have been permanently lobbied by staff members who wanted to increase their power and tried to increase the number of conditions included in programs (de Vries and Horsefield, 1969: 270). In the first years of the Funds' operations, Directors resisted this pressure. Over time, however, staff members became relatively more powerful. As Martin (2002: 23) points out, one reason for this development is that Executive Directors are replaced more frequently than staff members. As a consequence, staff members have an informational advantage over Executive Directors. Moreover, program negotiations soon started to be held in the borrowing countries' capitals which further accelerated the informational advantage of the staff and thus its power.

Formally, the principle of conditionality was included in the Fund's Articles of Agreement only in 1969. Obviously, the inclusion was in the interest of its staff. Developing countries' governments (and their Executive Directors) supported the formalization as well. Since the industrialized countries' majority in the Board insisted on various conditions anyhow, they probably hoped to achieve a more equal treatment. As a consequence of the formalization, IMF staff was able to demand - on average - more conditions than before. Therefore the number of conditions should have increased after 1969. To the contrary, the seventies have been a period of comparatively loose conditionality. At this time, partly as a consequence of rising oil prices, private 
credit has been available in sufficient amounts. Oil exporting countries channelled their money to the international banking system which could lend it in turn. Most countries with middle and higher income could therefore get private capital without accepting any conditionality. The IFIs thus faced a sharp decline in demand for their resources and were prepared to lend with fewer conditions attached (Kapur, Lewis, and Webb, 1997: 463). Since industrialized countries' demand declined at the same time, this tendency was further enhanced. The IFIs have only been able to reduce the excess in supply by lending their money with less conditionality.

In the following years, the number of conditions steadily increased. One possible explanation for this rising number might be the declining interest of (powerful) industrial countries in the IFIs as provider of credit. Industrial countries received loans from the World Bank only immediately after the Second World War and after 1976 no industrialized country applied for an IMF program. They have been, however, potential IMF borrowers until the eighties, even though with declining probability. Since governments tend to endorse more stringent conditionality the less the likelihood to be subject to conditions themselves, the changing nature of possible IFI clients might have contributed to the increase in the number of conditions. At the same time, private money ceased to be available as Latin American countries fell into arrears. For many developing countries the sole possibility to get new loans was to negotiate programs with IMF or World Bank. Confronted with higher demand for their resources, the IFIs demanded more and more conditions.

As a consequence of the Asian crisis, the IFIs again faced a rising demand for their money and governments which were desperate enough to agree on virtually all kinds of conditions to get the required international reserves. Again the IMF reacted with an increase in the number of conditions. ${ }^{4}$ Prior to the Asian crisis, these countries have been successful without much help from the IFIs. It seems that the IMF seized the chance to imprint its policy on the Asian economies. Another explanation is that the additional conditions reflect the lessons learned during the crisis. IMF staff did, however, not dispense with the conditions included formerly, so total conditions increased. If this pattern prevails, the number of conditions would rise with every new crisis.

Another reason for the increasing number of conditions is the changing consensus over what "good" economic policy looks like. At the beginning of the eighties, Thatcher in Great Britain and Reagan in the United States promoted their neo-liberal policies. Both politicians tried to cut back the role of the state, reduce subsidies, liberalize markets and privatize public enterprises (Buira, 2002). As a result of these reforms, structural aspects came into the focus of adjustment programs as well. Many of the new conditions refer to such structural aspects. Between 1985-86 less than 20 percent of upper 
credit tranche arrangements included conditions related to structural measures (IMF, 2001: 8). At the end of the decade, such conditions were covered under almost two thirds of the arrangements whereas by the mid nineties they were included in almost all programs (IMF, 2001: 9). The IMF claims that reforms of industrialized countries in these areas made it aware of problems with developing countries' policies as well (IMF, 2001: 12). Relationships with economists outside Fund and Bank could also be responsible for the surge in structural conditions. Those economists started to attribute economic growth to structural and institutional factors. Four additional reasons for the new orientation have been proposed by Buira (2002: 23): First, resistance against such reforms declined in many developing countries as economists educated in the U.S. increasingly took part in governments who were, as a consequence, open minded to the new ideas. Second, the IMF wanted to refute counter its critics who claimed the Fund's concepts would reduce demand and therefore aggravate the crisis instead of contributing to its solution. Third, debt relief under the Brady plan was connected with structural reforms. Fourth, the Fund became increasingly responsible for the surveillance of its members' economic policies. This made existing structural imbalances more obvious for IMF staff.

Arguing along similar lines, the differences in Fund and Bank conditionality can be explained. In the first thirty years of its existence, the IMF's conditionality was less specific than today and covered a smaller range of policies. At this time, however, the World Bank enforced even fewer conditions than the Fund.

The most important reason for this weak conditionality is probably that the Bank did not have the leverage to negotiate agreements with highest government branches. At this time, adjustment lending accounted for only a small fraction of the World Bank's loans. It was therefore impossible for the Bank to prescribe detailed conditions.

Today, the number of conditions included in Bank programs are even more numerous than those enforced by the Fund. As one explanation, industrialized countries went to the Bank only immediately after the World War but received Fund credits until the mid-seventies. Some of them probably regarded the IMF as a potential source for money until the eighties, even with declining probability over time.

Numerous conditions increase the Bank's leeway. If certain conditions are not fulfilled, the Bank can justify disbursement with the fact that most conditions have been implemented. It has already been explained that the Bank has no interest in retaining its money. This is probably one reason why the Bank employs conditions which are less specific than those of the Fund. It would be much more difficult to disburse tranches when clear quantitative 
conditions have been breached. The less specific the conditions, the easier it is for the Bank to justify disbursements.

Another reason for differences in conditionality is the risk of default in the case of the Bank. Arrears to the Fund would immediately cut off a country from all (private and official) money. The IMF can also dispense a country's voting and other membership rights if it falls in arrears to it. This induces countries to repay the Fund even if debt service to all other creditors has been suspended. Contrary to the Bank, the Fund can even lend into arrears to avoid outright default. The Bank's Articles do not permit such a procedure. In order to secure its loans, the Bank therefore demands more reforms than the Fund.

For the organizations, exactly quantifiable conditions are the more problematic, the easier it is for the public to access information about those conditions. The Bank's preference for many, unspecific conditions was probably enhanced as its relations with the public have for most of its existence been much more open compared to those of the Fund.

\subsection{Hypotheses}

This section develops hypotheses about why governments of poorer countries could not achieve their aim of equal treatment of developed and industrialized countries and why programs with countries at similar stages of development include different conditions as well. Article 9 of the IMF's Articles gives a first hint. This article states that content and number of conditions may vary in different programs, since both the reasons for concluding a program and the borrowers' institutions differ. With respect to the last point, differences between developing and industrialized countries are obvious. In a similar manner, the quality of politics differs between different creditor countries. Therefore, from a normative perspective, IMF and World Bank should be more demanding, the worse the borrowing country's policies. Traditionally, the IMF focuses on government consumption, a country's current account balance and its rate of monetary growth. For both institutions, restrictions in trade and capital movements and therefore the amount of economic freedom governments grant their citizens are important. We would thus expect that:

Hypothesis 1. IMF and World Bank demand fewer conditions from countries with more economic freedom, lower monetary growth, higher current account balances and lower government consumption.

Fund and Bank lending is often justified on humanitarian grounds. Apart from the quality of the governments' policies, humanitarian aspects should therefore be important in negotiating conditions. In programs to some countries, an improvement in government policies should be less important 
for the institutions since they provide loans mostly for humanitarian reasons. Such loans are most likely to be provided by the International Development Agency (IDA) and under the IMF's Poverty Reduction and Growth Facility (PRGF). All else equal, the institutions should thus be less demanding under these facilities:

Hypothesis 2. PRGF-programs include fewer conditions. The same is true for loans provided by the IDA.

Independent of economic policy and humanitarian aspects the Fund should be more demanding, the greater the volume of loans provided relative to the country's quota. This is official Fund procedure since 1955 (IMF, 1955: 84). I thus hypothesize that:

Hypothesis 3. The Fund enforces more conditions, the greater the volume of loans provided relative to a country's quota.

Further explanations for variations in conditionality are provided by public choice theory. If IMF and Bank staff is interested in enforcing as many conditions as possible, they negotiate more stringent programs with countries in a weak bargaining position. The possibility to enforce its own agenda in negotiations with the IFIs is worse, the more a government is in need of IMF or Bank loans. Moreover, a countries' power to negotiate is influenced by other countries' willingness to support the potential borrowers (Bird and Rowlands, 2003). Both a country's own (direct) influence in the institutions and support by other countries probably rise with its GDP. Countries with higher GDP are more important for the world economy. Moreover, their quota with the Fund is higher which results in higher voting rights:

Hypothesis 4. Countries with lower GDP must accept more conditions.

In addition to a country's overall importance for the world economy and its government's influence in the institutions' boards, countries are more likely to receive low conditionality loans if their request is supported by the government of the U.S.A. - the most influential shareholder of the institutions. I expect that:

Hypothesis 5. Fund and Bank are less demanding if a borrowing country is supported by the U.S.A. 
Sometimes governments press the IFIs to lend to countries which are in arrears to them or their banks. Fund and Bank might want to lend to those countries in order to avoid outright default. The bargaining position of the institutions is therefore weaker and, thus, their conditionality should be less stringent:

Hypothesis 6a. Fund and Bank enforce less conditions if a country is in arrears to its creditors.

On the other hand, arrears could even lead to an increase in the overall number of conditions. This would be if, in the absence of arrears, the Fund would not lend to such a country at all. The arrangements would probably include more conditions than others - especially conditions to secure clearance of the arrears:

Hypothesis $6 b$. Fund and Bank enforce more conditions if a country is in arrears to its creditors.

Another important question is whether (and why) the IFIs vary their conditionality in line with business cycles. According to Cooper (1983), the IMF should lend with fewer stringent conditions attached in recessions and more conditions if economies are booming. This proposal rests on the assumption that in spite of the conditions demanded, credits are expansionary (Cornelius, 1988: 217). The extent of the expansionary stimulus could be controlled by variations in the stringency of conditionality. According to public choice theory, quite the contrary, the Fund would even be more stringent in recessions instead of being less demanding, however. This is because IMF members need more loans in recessions and the Fund has therefore more power to impose more (and tougher) conditions (Vaubel, 1994: 53). This leads support to the hypothesis:

Hypothesis 7. The IFIs enforce more conditions in recessions.

In recessions, the IFIs might have a catalytic role in channeling private money. For example, as a consequence of the debt crisis, most private and bilateral lenders only agreed to lend if a program with the IMF was in place (Gould, 2001; Bird and Rowlands, 1997). Since Fund and Bank did not dispose of resources sufficient to solve the crisis, they did depend to some extent on private banks who attached their money to the IFIs' programs. In turn, private banks could enforce conditions in the IFIs' programs which were in their interest (Gould, 2001). Moreover, Fund and Bank become 
more powerful if private credits are conditional on their programs. They can therefore enforce more conditions:

Hypothesis $8 a$. Conditionality is stronger if private lenders attach their money to a program.

On the other hand, however, the IFIs' power is reduced if private money is borrowed to substitute for their resources. In this case Fund and Bank would lend with fewer conditions, since otherwise demand for their loans would decline. Then,

Hypothesis $8 b$. Conditionality is softer if private lenders attach their money to a program.

At the end of the eighties, private loans surged again and the bargaining power of the IFIs was greatly weakened by their member countries' access to alternative sources of credit (Mosley, Harrigan, and Toye, 1991). On the other hand, with the end of the Cold War, the risk that countries turned to the enemy if Fund and Bank were to demanding disappeared. With the decline of the Soviet Union, the U.S.A. might have lost some of its interest in instrumentalising the IFIs to do its 'dirty work' ${ }^{5}$ It therefore became more difficult for allied and neutral countries to get low conditionality loans after 1990. The countries emanating from the Soviet Union showed an enormous demand for the financial institutions' loans. I therefore hypothesize:

Hypothesis 9. Conditionality is stronger after 1990.

As more and more borrowers of the IFIs became more democratic, criticism about the authoritarian nature of conditionality increased. While it seemed to be acceptable to impose conditionality on dictatorships, the institutions were now under pressure to pay due regard to the borrowers' own development concepts. Moreover, there was increasing pressure to publish the attached conditions. This public interest made it more difficult to pay out tranches at will when conditions were not implemented. In order to increase their leeway, it was obviously in the interest of the staff to increase the number of less easily monitorable, less specific conditions.

For the reasons introduced above, democratic governments might ask for conditions in their interest to be included in the programs. These conditions would probably be easy to comply with or would enhance the governments' position vis-a-vis internal opposition. ${ }^{6}$ I hypothesize: 
Hypothesis 10. The number of conditions increases with democracy.

Another important possibility to explain changes in conditionality over time and across countries might be the changing relationship between the IFIs themselves. With the inception of the Fund's Extended Facility in 1974 and the Banks' Structural Adjustment Loans (SALs) in 1980, the demarcation line between Bank and Fund became blurred. In the eighties, Fund and Bank were rivals for adjustment lending. In some cases the Bank supported countries in spite of negative Fund evaluations. ${ }^{7}$ The Fund therefore faced the risk of losing its clients if the Bank marketed its macroeconomic programs with softer conditionality. To avoid this kind of competition and contradictory advice the IMF tried to press for more cooperation (Polak, 1994: 39). The IFIs started to send members of their staff to the other organization's mission teams. This improved the range of competences in those teams and therefore the possible scope for conditionality. This range of conditions covered under the IFIs' programs might have been expanded further by the rising cooperation between Bank and Fund in other areas as well. For example, conclusion of a Fund program is a precondition for the Bank's SALs. This kind of cooperation is explicitly mentioned under the Bank's Articles of Agreement. Paragraph 8(b) states that

In making decisions on applications for loans or guarantees relating to matters directly within the competence of any international organization (...) the Bank shall give consideration to the views and recommendations of such organization.

As has been shown by Dreher (2002), this principle is applied in practice. 35\% of the Bank's Country Assistance Strategy Papers between 1998-2000 include obedience to Fund conditionality as trigger. With respect to the IMF, this collaboration is not provided for under its Articles of Agreement. Nevertheless, Fund programs do depend in some ways on the Bank. As one example, disbursements programmed under the Bank's SALs are usually part of the revenue anticipated by Fund arrangements when performance criteria are settled. Delay in Bank disbursements could therefore imply that Fund performance criteria are missed and the program interrupts (Polak, 1994: 15). Moreover, due to the close cooperation between the two institutions, Fund staff takes the Bank's view of a governments' policy into account. In 1966 this was explicitly agreed upon in a memorandum where Fund and Bank agreed on their respective areas of competence. In this memorandum, Fund and Bank contracted to consult each other's staff on matters of their core competence 
before starting to negotiate with the borrowing country's government. This interchange is reinforced by the joint country missions.

Another area of collaboration is the preparation of reform programs for member countries. Until January 2000, Bank and Fund staff together drafted Policy Framework Papers. Since then, Policy Framework Papers are being replaced by Poverty Reduction Strategy Papers (PRSP) which are prepared in closer collaboration with government staff. ${ }^{8}$ Nevertheless, since programs of both institutions base on the jointly prepared PRSP, the Fund adopts part of the Bank's conditionality, though not explicitly, but as part of its own program. The same is true for the Bank. Thus,

Hypothesis 11. The number of conditions is expected to be higher, the higher is the sister institutions' contemporaneous involvement in a country.

I proceed with testing the hypotheses.

\subsection{Empirical estimates}

I test the postulated hypotheses empirically for the IMF. They are valid for the World Bank also. However, since the Bank does not publish conditions included in individual programs, the empirical part has to concentrate on the Fund. The number of Fund conditions plays a prominent role in the current debate over conditionality reforms. The IMF (2001) has used them in empirical analysis as well.

The dependent variable is the number of performance criteria and structural benchmarks in IMF programs concluded with 43 countries. $^{9}$

The regression is a pooled time-series cross-section analysis (panel data). The annual data cover the years 1987-99. For about half of the countries in the sample the independent variable is available for only one year. The maximum number of observations for one country is three years. Therefore, the panel is unbalanced. Moreover, the number of observations depends on the choice of explanatory variables.

In the estimations presented below, I use a poisson model to predict the number of conditions. A hausman test did not reject random effects, so this specification is used. ${ }^{10}$ Descriptive statistics and data sources are given in the Appendix.

Column 1 of Table 1 starts with testing the hypotheses derived from public choice theory. As can be seen, World Bank adjustment programs and technical programs concluded in the same year as the IMF program have a significantly positive influence on the number of IMF conditions, while the effect of all other World Bank projects is insignificant. The coefficients of the first two variables are in line with the hypotheses of re-inforcing activities 
of the two institutions. If additional covariates are included in the regression, however, only the number of adjustment programs keep their significant influence. The coefficients of the three World Bank variables are jointly significant at the one percent level $(\mathrm{F}=12.01)$. The hypotheses of equal coefficients of the different types of programs can be rejected $(\mathrm{F}=12.07)$.

As the results show, most of the other covariates have no significant influence on the number of conditions. The only exception is the dummy for the period after 1990. Its coefficient is highly significant, with a positive sign. Neither the interests of the U.S. (proxied by U.S. loans and military aid) nor those of other bilateral or commercial creditors (proxied by public and publicly guaranteed debt outstanding to them) influence the number of IMF conditions significantly. While the insignificant coefficient of commercial debt could emerge because the number of conditions included due to pressure of private banks offsets the Fund's weaker bargaining position if private loans are used as substitutes for its own loans, the insignificant coefficients of the other variables are surprising. The variables are not only proxies for the interests of creditors in Fund money for those countries. As already mentioned, these loans could also serve as substitutes for IMF credits. Both effects should result in fewer conditions. The coefficients of a country's GDP, its arrears and its level of democracy ${ }^{11}$ are also insignificant. World business cycles - proxied by GDP growth rates in OECD countries - have no influence on the number of conditions as well.

The second column includes the variables from normative theory instead of the public choice variables. The number of conditions is significantly higher with higher government consumption, more exhausted credit lines in the Fund and lower with greater economic freedom. ${ }^{12}$ This is in line with the hypotheses. Monetary expansion leads to significantly fewer conditions, which is surprising. Its coefficient is not robust to the inclusion of the public choice variables, however. The country's current account balance does not influence the number of conditions. A dummy for the PRGF is also insignificant.

The third column includes both normative and public choice variables. All variables with a coefficient significant at the ten percent level the least, are accepted for the final specification (column 4). As can be seen, only four of the hypotheses postulated above found support in the empirical analysis: The IMF tends to include more conditions, the more adjustment programs are concluded with the World Bank in the same year. As explained, this is probably because Fund and Bank staff use existing Bank material when they jointly prepare IMF programs. They include part of the Bank's conditions into IMF programs. The influence is quantitatively relevant. An additional adjustment program raises, all else equal, the number of conditions by 0.28 . Since the 
Table 1. Number of IMF conditions (panel data, 43 countries, 1987-99, poisson)

\begin{tabular}{|c|c|c|c|c|}
\hline & (1) & (2) & (3) & (4) \\
\hline World bank adjustment loans & $\begin{array}{l}0.17 \\
\left(2.15^{* *}\right)\end{array}$ & & $\begin{array}{l}0.18 \\
\left(1.89^{* * *}\right)\end{array}$ & $\begin{array}{l}0.28 \\
\left(4.83^{*}\right)\end{array}$ \\
\hline World bank other loans & $\begin{array}{l}-0.03 \\
(-0.96)\end{array}$ & & $\begin{array}{l}-0.02 \\
(-0.58)\end{array}$ & \\
\hline World bank technical loans & $\begin{array}{l}0.23 \\
\left(1.78^{* * *}\right)\end{array}$ & & $\begin{array}{c}0.16 \\
(0.96)\end{array}$ & \\
\hline Principal arrears (in percent of GDP) & $\begin{array}{l}-0.48 \\
(-1.06)\end{array}$ & & $\begin{array}{l}-3.08 \\
(-1.17)\end{array}$ & \\
\hline $\begin{array}{l}\text { U.S. military grants (relative to } \\
\text { IMF disbursements) }\end{array}$ & $\begin{array}{c}0.02 \\
(0.54)\end{array}$ & & $\begin{array}{c}0.02 \\
(0.45)\end{array}$ & \\
\hline U.S. loans (relative to IMF disbursements) & $\begin{array}{c}0.01 \\
(0.17)\end{array}$ & & $\begin{array}{c}0.03 \\
(0.44)\end{array}$ & \\
\hline $\begin{array}{l}\text { Public and publicly guaranteed debt, } \\
\text { bilateral (relative to IMF disbursements) }\end{array}$ & $\begin{array}{l}-0.001 \\
(-0.33)\end{array}$ & & $\begin{array}{l}-0.002 \\
(-0.67)\end{array}$ & \\
\hline $\begin{array}{l}\text { Public and publicly guaranteed debt, } \\
\text { commercial (relative to IMF disbursements) }\end{array}$ & $\begin{array}{l}0.0001 \\
(0.40)\end{array}$ & & $\begin{array}{l}0.0002 \\
(0.72)\end{array}$ & \\
\hline GDP & $\begin{array}{l}-0.0002 \\
(-0.44)\end{array}$ & & $\begin{array}{l}-0.001 \\
(-1.19)\end{array}$ & \\
\hline GDP per capita growth in OECD countries & $\begin{array}{c}0.09 \\
(1.38)\end{array}$ & & $\begin{array}{c}0.03 \\
(0.46)\end{array}$ & \\
\hline Democracy, index & $\begin{array}{c}0.02 \\
(0.90)\end{array}$ & & $\begin{array}{c}0.02 \\
(0.82)\end{array}$ & \\
\hline Post-1990, dummy & $\begin{array}{l}1.34 \\
\left(8.64^{*}\right)\end{array}$ & & $\begin{array}{l}1.42 \\
\left(7.56^{*}\right)\end{array}$ & $\begin{array}{c}1.30 \\
\left(15.81^{*}\right)\end{array}$ \\
\hline $\begin{array}{l}\text { Government consumption (in percent of } \\
\text { GDP) }\end{array}$ & & $\begin{array}{l}0.10 \\
\left(2.83^{*}\right)\end{array}$ & $\begin{array}{l}-0.03 \\
(-0.57)\end{array}$ & \\
\hline Monetary expansion (percent) & & $\begin{array}{l}-0.0004 \\
\left(-1.74^{* * *}\right)\end{array}$ & $\begin{array}{l}-0.0001 \\
(-0.60)\end{array}$ & \\
\hline Current account balance (in percent of GDP) & & $\begin{array}{l}-0.72 \\
(-0.50)\end{array}$ & $\begin{array}{l}-3.43 \\
\left(-2.09^{* *}\right)\end{array}$ & $\begin{array}{l}-1.96 \\
\left(-2.31^{* *}\right)\end{array}$ \\
\hline Economic freedom, index & & $\begin{array}{l}-0.16 \\
\left(-2.25^{* *}\right)\end{array}$ & $\begin{array}{l}-0.11 \\
\left(-1.81^{* * *}\right)\end{array}$ & $\begin{array}{l}-0.13 \\
\left(-4.62^{*}\right)\end{array}$ \\
\hline Change in IMF liabilities (in percent of quota) & & $\begin{array}{c}0.002 \\
\left(1.95^{* * *}\right)\end{array}$ & $\begin{array}{l}-0.0003 \\
(-0.21)\end{array}$ & \\
\hline PRGF, dummy & & $\begin{array}{c}0.32 \\
(1.26)\end{array}$ & $\begin{array}{l}-0.58 \\
\left(-2.72^{*}\right)\end{array}$ & $\begin{array}{c}-0.45 \\
\left(-3.48^{*}\right)\end{array}$ \\
\hline Constant & $\begin{array}{c}1.78 \\
\left(8.99^{*}\right)\end{array}$ & $\begin{array}{l}3.08 \\
\left(8.15^{*}\right)\end{array}$ & $\begin{array}{c}2.42 \\
\left(5.16^{*}\right)\end{array}$ & $\begin{array}{c}2.47 \\
\left(15.82^{*}\right)\end{array}$ \\
\hline Log likelihood & -115.30 & -173.30 & -89.26 & -136.94 \\
\hline Number of countries & 36 & 43 & 32 & 42 \\
\hline Number of observations & 43 & 56 & 38 & 54 \\
\hline
\end{tabular}

Notes. z-statistics in parentheses. Levels of significance: $1 \%\left(^{*}\right), 5 \%\left({ }^{* *}\right), 10 \%\left({ }^{* * *}\right)$. 
maximum number of adjustment programs included in the data is four, those programs are responsible for 1.12 additional conditions at the highest. Programs include fewer conditions with higher economic freedom and a higher current account balance which both proxy the quality of a country's economic policies as perceived by the IMF. Controlled for other factors, conditions are also less numerous under the PRGF. If the regression controls for a country's economic situation and political weight, the IMF enforces fewer conditions under this facility, probably due to humanitarian reasons. Programs include more conditions after 1990. As Column 4 shows, the current account balance is significant at the five percent level while the other variables are significant at the one percent level.

To check for the robustness of the results, a number of additional variables has been included. ${ }^{13}$ Neither of the additional variables has a significant influence on the number of conditions. All previous results remain. As an additional test, all regressions have been repeated with one country excluded each time. Again the results are unchanged.

\section{Summary}

The paper explained IMF and World Bank lending and conditionality from a public choice perspective. It has been argued that changes in relative bargaining power of different stakeholders over time are crucial for the IFIs' evolution. Using panel data, the number of IMF conditions in 43 countries between 1987-99 has been explained empirically. The analysis has shown, that IMF conditions increase with contemporaneous engagement of the World Bank and "bad" economic policies. Moreover, all else equal, programs concluded after 1990 include more conditions while programs under the Poverty Reduction and Growth Facility include fewer conditions.

Given the limited availability of data, the hypotheses could not be tested for the World Bank. This might be a promising area for future research.

\section{Notes}

1. Bird (1986) provides an overview.

2. This presupposes that there is a connection between the stringency of a program and the number of conditions included.

3. Staff members change region every $3-5$ years.

4. In 1997, there were on average 20 conditions included in programs with Asian countries, compared with an average of 16 conditions for all countries (Goldstein, 2000: Table 4).

5. The 'dirty work' hypotheses was introduced by Vaubel (1986: 48). 
6. Unfortunately the letters of intent do not indicate which conditions have been demanded by the Fund. Whether conditionality became easier to comply with in recent years is an interesting question for future studies.

7. In 1988 this was the case in Argentina and Turkey (Polak, 1994: 37).

8. This might also help explain why the PRSP-based Poverty Reduction and Growth Facility loans include more structural conditions compared to Standby Arrangements where BankFund collaboration is less intense.

9. Some basic performance criteria are included in almost all programs so that without the inclusion of structural benchmarks variation is small. Moreover, though non-compliance with structural benchmarks does not immediately interrupt IMF programs they constitute an important part of Fund conditionality (IMF, 2001: 5). Prior actions are not included, since these data are available only exceptionally.

10. Since some of the assumptions underlying the poisson model are quite restrictive, a negative binomial model and a simple OLS specification have also been estimated. However, as the results are almost identical, these estimations are not reported.

11. To measure democracy, the Polity IV indicator is used. It takes values from zero (not democratic) to 10 (democratic).

12. Economic freedom is measured by an index constructed by Gwartney et al. (2000). It takes values from zero (not free) to 10 (free).

13. The following variables have been used: domestic absorption, changes in international reserves, arms imports, military expenditures, interest in arrears, aid received (all in percent of GDP), openness and rate of inflation.

\section{References}

Bird, G. (1986). Relationships, resource uses and the conditionality debate. In T. Killick (Ed.), The quest for economic stabilisation: The IMF and the Third World, 145-182. Aldershot: Gower Publishing Company Ltd.

Bird, G. (2002). Conditionality and ownership: How to improve the implementation of IMF programmes. Unpublished manuscript. University of Surrey.

Bird, G. and Rowlands, D. (1997). The catalytic effect of lending by the International Financial Institutions. World Economy 20: 967-991.

Bird, G. and Rowlands, D. (2003). Political economy influences within the life-cycle of IMF programmes. World Economy 9: 1255-1278.

Buira, A. (2002). An analysis of IMF conditionality: Group of twenty-four on International Monetary Affairs Research Program. Unpublished manuscript.

Cooper, R.N. (1983). Panel discussion. In J. Williamson (Ed.), IMF conditionality, 569-577. Cambridge, MA: Institute for International Economics.

Cornelius, P. (1988): Das Prinzip der Konditionalität bei Krediten des internationalen Währungsfonds. München: Verlag V. Florentz GmbH.

Deutsche Bundesbank (1997). Weltweite Organisationen und Gremien im Bereich von Währung und Wirtschaft. Frankfurt a.M.

Dhonte, P. (1997). Conditionality as an instrument of borrower credibility. Paper on Policy Analysis and Assessment 97/2. Washington, DC: IMF.

Dollar, D. and Svensson, J. (1998). What explains the success or failure of structural adjustment programs? Policy Research Paper 1938. Washington, DC: World Bank. 
Dreher, A. (2002). The development and implementation of IMF and World Bank conditionality. Hamburg: HWWA Discussion Paper 165.

Dreher, A. and Vaubel, R. (2004). Do IMF and IBRD cause moral hazard and political business cycles? Evidence from panel data. Open Economies Review 15: 5-22.

Frey, B.S. (1997). The public choice of international organizations. In D.C. Mueller (Ed.), Perspectives on public choice, 106-123. Cambridge: Cambridge University Press.

Goldstein, M. (2000). IMF Structural Programs. In M. Feldstein (Ed.), Economic and financial crises in emerging market economies, 363-437. Chicago: University of Chicago.

Gould, E.R. (2001). The changing activities of international organizations: The case of the international monetary fund. Paper presented at the APSA 2001 conference. Unpublished manuscript.

Gwartney, J., Lawson, R. and Samida, D. (2000). Economic freedom of the world 2000. Annual Report, http://freetheworld.com.

International Bank for Reconstruction and Development (2000). Global development finance. CD-ROM, Washington, DC.

International Bank for Reconstruction and Development (2000a). World development indicators. CD-ROM, Washington, DC.

International Financial Institutions Advisory Commission (1999). Report, http://phantomx.gsia.cmu.edu/IFIAC/USMRPTDV.html, 1.9.2000.

International Monetary Fund (1955). Annual report, Washington, DC.

International Monetary Fund (2001). Structural conditionality in fund-supported programs, 16 February; http://www.imf.org.

International Monetary Fund (2001a). Conditionality in fund-supported programs - Policy issues, 16 February; http://www.imf.org.

International Monetary Fund (2001b). Trade policy conditionality in fund-supported programs, 16 February; http://www.imf.org.

International Monetary Fund (2002). International financial statistics indicators, CD-ROM. Washington, DC.

Kahler, M. (1986). Conclusion: Politics and proposals for reform. In M. Kahler (Ed.), The politics of international debt, 245-272. London: Cornell University Press.

Kaltefleiter, V. (1995). Die Entwicklungshilfe der europäischen Union. Wirtschaftswissenschaftliche Beiträge 112. Heidelberg: Physica-Verlag.

Kapur, D., Lewis, J.P. and Webb, R. (1997). The World Bank - Its first half century, Vol. 1. Washington, DC: Brookings Institution Press.

Marshall, M.G. and Jaggers, K. (2000). Polity IV Project. Political regime characteristics and transitions, 1800-1999; http://www.cidem.umd.edu/inser/polity/.

Martin, L.L. (2002). Distribution, information, and delegation to international organizations: The case of IMF conditionality. Unpublished manuscript. Harvard University.

Mosley, P., Harrigan, J. and Toye, J. (1991). Aid and power - The World Bank \& policy-based lending, Vol. 1. New York: Routledge.

Nash, J. (1993). Implementation of trade reform in Sub-Saharan Africa - How much heat and how much light? Policy Research Working Paper 1218. Washington DC: World Bank.

Polak, J.J. (1994). The World Bank and the IMF - A changing relationship. Brookings Occasional Papers. Washington, DC.

Ranis, G. (1996). On fast-disbursing policy loans. Background paper prepared for the Task Force on the United States and Multilateral Development Banks. Center for Strategic and International Studies. Washington, DC. 
Schadler, S., Bennett, A., Carkovic, M., Dicks-Mireaux, L., Mecagni, M., Morsink, J.H.J. and Savastano, M.A. (1995). IMF conditionality: Experience under stand-by and extended arrangements, Part II: Background papers. IMF Occasional Paper 129. Washington, DC.

Vaubel, R. (1986). A public choice approach to international organisation. Public Choice, 51: $39-57$.

Vaubel, R. (1991). The political economy of the International Monetary Fund: A public choice approach. In R. Vaubel and T.D. Willett (Eds.), The political economy of international organisations, 205-245. Boulder: Westview.

Vaubel, R. (1994). The political economy of the IMF: A public choice analysis. In D. Bandow and I. Vásquez (Eds.), Perpetuating poverty - The World Bank, the IMF, and the developing world, 37-55. Washington, DC: Cato Institute.

Vreeland, J.R. (2001). Institutional determinants of IMF agreements. Unpublished manuscript. Department of Political Science, Yale University, New Haven.

Vries, M.G. de and Horsefield, J.K. (1969). The International Monetary Fund, 1945-1965: Twenty years of international monetary cooperation. Washington, DC: IMF.

World Bank (2001). Adjustment lending retrospective. Final Report, Operations Policy and Country Services. Washington, DC. 
Appendix 1. Descriptive statistics and data sources (within sample)

\begin{tabular}{|c|c|c|c|}
\hline Variable & Data source & Mean & SD \\
\hline Number of conditions & $\begin{array}{l}\text { Schadler et al. (1995), letters } \\
\text { of intent (www.imf.org) }\end{array}$ & 16.69 & 12.18 \\
\hline \multicolumn{4}{|l|}{ World Bank adjustment } \\
\hline loans & www.worldbank.org & 0.61 & 0.75 \\
\hline World Bank technical loans & www.worldbank.org & 0.18 & 0.38 \\
\hline World Bank other loans & www.worldbank.org & 2.29 & 2.29 \\
\hline Principal arrears (in percent of & & & \\
\hline GDP) & IBRD (2000) & 0.05 & 0.11 \\
\hline U.S. military grants (relative to & & & \\
\hline IMF disbursements) & USAID, www.qesdb.cdie.org & 0.41 & 2.16 \\
\hline $\begin{array}{l}\text { U.S. loans (relative to IMF } \\
\text { disbursements) }\end{array}$ & USAID, www.qesdb.cdie.org & 1.06 & 1.84 \\
\hline $\begin{array}{l}\text { Public and publicly } \\
\text { guaranteed bilateral debt }\end{array}$ & & & \\
\hline (relative to IMF disbursements) & IBRD (2000) & 25.62 & 40.38 \\
\hline $\begin{array}{l}\text { Public and publicly } \\
\text { guaranteed commercial debt }\end{array}$ & & & \\
\hline (relative to IMF disbursements) & IBRD (2000) & 125.16 & 438.56 \\
\hline GDP (billion US\$, real) & IBRD (2000a) & 60.22 & 127.21 \\
\hline $\begin{array}{l}\text { Per capita GDP growth rate } \\
\text { (OECD countries) }\end{array}$ & IBRD (2000a) & 2.54 & 1.20 \\
\hline $\begin{array}{l}\text { Government consumption } \\
\text { (in percent of GDP) }\end{array}$ & IBRD (2000a) & 1.85 & 2.58 \\
\hline Monetary expansion (percent) & IBRD (2000a) & 84.30 & 333.67 \\
\hline $\begin{array}{l}\text { Current account balance } \\
\text { (in percent of GDP) }\end{array}$ & IBRD (2000a) & -0.03 & 0.07 \\
\hline Economic freedom, index & Gwartney et al. (2000) & 5.46 & 1.47 \\
\hline Democracy, index & Marshall and Jaggers (2000) & 5.17 & 3.67 \\
\hline $\begin{array}{l}\text { Change in IMF liabilities } \\
\text { (percent of quota) }\end{array}$ & IMF (2002) & 21.90 & 130.81 \\
\hline
\end{tabular}

